\title{
Culture Compounds which are Able to Increase the Growth and the Production of Bacteriocins by Two Different LABS
}

\author{
Immacolata Anacarso*, Moreno Bondi, Cinzia Mura, Simona de Niederhäusern, Ramona Iseppi, Patrizia Messi, Carla Sabia and Carla \\ Condò
}

Department of Life Sciences, University of Modena and Reggio E., Via Campi, 287-41125 Modena, Italy

\begin{abstract}
The exact composition of a culture medium used to grow bacteria and to provide the best conditions for the production of bacteriocins is very important. For this study two bacteriocins were used: enterocin $416 \mathrm{k} 1$, produced by Enterococcus casselliflavus $416 \mathrm{~K} 1$, and nisin A, produced by Lactococcus lactis ATCC 11454; both Listeria monocytogenes inhibitors. The bacteriocin producers were cultured with various substances, including vitamins, salts, protein extracts and detergent, at three concentrations. In the first step, the individual substances were tested as additional nutrients, in order to evaluate their effects on the production of bacteriocins; subsequently the substances which were able to increase the production of bacteriocins were combined together, to investigate the presence of any synergism or antagonism. The most significant consideration that arises is the different behaviors of the microorganisms in response to the addition of the same substances. Furthermore, different results were seen depending on the concentrations of the substances. Bacteriocins have great potential in a variety of fields which means that large-scale production of these substances would be necessary. In this study we have tested different substances and combinations of substances which were able to increase the production of bacteriocins.
\end{abstract}

Keywords: Bacteriocins; Nisin; Enterocin; Lactobacillus; Enterococcus

\section{Introduction}

Lactic acid bacteria (LAB) are Gram-positive microorganisms, nonsporulating and acid-tolerant; many species of these are recognized as safe (GRAS) and for this reason they are the subject of many studies [1].

The LAB is able to produce protein substances, indicated as bacteriocins, which have antimicrobial activity against other closely related species [2]. They are heterogeneous compounds which are ribosomal synthetized, with different chemical properties, molecular weights, spectrums of activity and modes of action [3] and, according to their characteristics; they are categorized into three groups: class I- lantibiotics; class II- heat stable unmodified bacteriocins; class IIIlarger heat labile bacteriocins [4].

The use of bacteriocins from LAB may offer a promising solution, as nisin today is already used as a natural food preservative, in the future other similar substances may be used with the same purpose $[5,6]$ replacing in whole or in part chemical preservatives. Other future perspectives might be the use of these peptides in the therapeutic field, and many studies have been done [7], but no bacteriocin has a clinical application or is used for the control of food borne pathogens in livestock [8].

Several studies have demonstrated that LAB and their bacteriocins can be used for the control of Listeria monocytogenes and other food pathogens $[9,10]$. During recent years there has been more attention on the potential applications of bacteriocins in the protection of human health [11,12] in food preservation [13] and agriculture [14].

The production of bacteriocins is influenced by various environmental factors such as temperature, $\mathrm{pH}$ and nutrient sources $[15,16]$. With regard to nutrient sources, many studies have focused on different substances that increase the production of bacteriocins or the growth of microorganisms $[14,16,17]$. In this preliminary study, we focused our attention on how the nutritional resources can affect the production of bacteriocins. Several substances such as vitamins, salts, protein extracts and detergent substances were added to a base medium at three levels of concentration; at first these substances were added individually, as additional nutrients, and then were combined together, to assess the effects on growth and the production of bacteriocins (enterocin $416 \mathrm{~K} 1$ and nisin A) by Enterococcus casseliflavus $416 \mathrm{~K} 1$ and Lactococcus lactis ATCC 11454. The main aim was to determine the best conditions for the development and for the production of bacteriocins by Enterococcus casseliflavus $416 \mathrm{~K} 1$ and Lactococcus lactis ATCC 11454 by changing the conditions of the growth substrate. At the same time we wanted to discover if there were differences in terms of development and production of bacteriocins due to the addition of these substances to the basic medium for the two microorganisms tested.

\section{Materials and Methods}

\section{Bacterial strains, conditions of growth and culture media}

The bacterial strains used in this study were Enterococcus casseliflavus $416 \mathrm{~K} 1$, producer of enterocin $416 \mathrm{~K} 1$ - a bacteriocin with a high degree of anti-listeria activity, characterized in another work [18], and Lactococcus lactis ATCC 11454, known as producer of nisin A, the only bacteriocin currently employed as a food preservative.

*Corresponding author: Dr. Immacolata Anacarso, Department of Life Sciences University of Modena and Reggio E., Via Campi, 287-41125 Modena, Italy, Tel. +39 0592055795; Fax +39 0592055483; E-mail: immacolata.anacarso@unimore.it

Received August 19, 2014; Accepted September 26, 2014; Published September 28, 2014

Citation: Anacarso I, Bondi M, Mura C, de Niederhäusern S, Iseppi R, et al (2015) Culture Compounds which are Able to Increase the Growth and the Production of Bacteriocins by Two Different LABS. J Plant Pathol Microb 6: 263. doi:10.4172/2157-7471.1000263

Copyright: (c) 2015 Anacarso I, et al. This is an open-access article distributed under the terms of the Creative Commons Attribution License, which permits unrestricted use, distribution, and reproduction in any medium, provided the original author and source are credited. 
The initial conditions of the media used as a basic control for the growth of two bacteria and of their production of bacteriocin, were represented by Triptyc Soy broth (TSB, Oxoid, Italy) for Enterococcus casseliflavus $416 \mathrm{~K} 1$ and M17 broth (Biomerieux, Italy) for Lactococcus lactis ATCC 11454 and by incubation respectively at $37^{\circ} \mathrm{C}$ and $30^{\circ} \mathrm{C}$ for $24-48 \mathrm{~h}$.

The evaluation of the production bacteriocins by E. casseliflavus and L. lactis was made using agar well diffusion method as described below.

\section{Bacteriocin activity}

The culture of E. casseliflavus $416 \mathrm{~K} 1$ grown in TSB and of L. lactis ATCC 11454 grown in M17 broth, incubated under the set conditions, were centrifuged $\left(10,000 \mathrm{~g}\right.$ for $10 \mathrm{~min}$. at $\left.4^{\circ} \mathrm{C}\right)$ and dialyzed against 30 mmol L-1 sodium acetate buffer ( $\mathrm{pH} 5.3$ ), filter sterilized $(0.45 \mu \mathrm{m}$ pore-size filter; Millipore Corp., Bedfort, Mass.) to obtain the cell-free supernatant (CFSF) that were adjusted at $\mathrm{pH} 6$ with sterile $1 \mathrm{M} \mathrm{NaOH}$ and used as crude bacteriocins in the assay.

The activity of crude bacteriocins was tested by agar well diffusion assay, dispensing $100 \mathrm{ml}$ of both CFSFs into $8 \mathrm{~mm}$ diameter wells made in Triptych Soy Agar (TSA, Oxoid, Italy). After diffusion of the crude bacteriocins, plates were covered with $5 \mathrm{ml}$ of soft agar containing $10^{7}$ $\mathrm{cfu} / \mathrm{ml}$ of overnight cultures of L. monocytogenes NCTC 10888, used as indicator, and incubated at $30^{\circ} \mathrm{C}$ for $24 \mathrm{~h}$. The antimicrobial activity was shown by a clear zone of inhibition around the wells.

\section{Bacteriocin production under different conditions of growth}

Substances added individually: Five vitamins (B1, B2, B9, B3, C), Tween 80, four protein extracts (pepton, trypton, meat extract, yeast extract) and four different salts (sodium pyruvate, tetrazolium salts, ammonium sulphate, sodium sulphate), at three concentrations $(0.1,1$ and $10, \mathrm{~g} / \mathrm{l})$, were added singly to basic growth media, TSB and M17, for Enterococcus casseliflavus $416 \mathrm{~K} 1$ and Lactococcus lactis ATCC 11454 respectively, incubated at $37^{\circ}$ and $30^{\circ} \mathrm{C}$ for $24-48 \mathrm{~h}$, to evaluate the effects on the growth of the microorganisms and on their bacteriocin production.

The protein substances and different salts are commonly present in the growth media for enterococci and lactobacilli. Sodium pyruvate - the salt of pyruvic acid, was studied in particular as an exogenous factor in the production of bacteriocins [19]. We chose 4 of the principal protein extracts and 4 salts other than those present in the growth media, including sodium pyruvate, to evaluate their influence on growth and production of bacteriocins of the strains studied. The vitamins are essential for human, plant and bacteria, and the latter are often capable of synthetizing these substances $[20,21]$.

Vitamins of B group in particular, are known as essentials, and a different study focused on their role in the development of a variety of bacteria [22,23]. Vitamin C is a strongly antioxidant agent but little is known about its influence on bacteria [24]. For these reasons we chose vitamin $C$ and four $B$ group vitamins to evaluate their influence on the production of bacteriocins by two LABs.

The production of bacteriocin was evaluated by agar well diffusion assay, before measuring the $\mathrm{pH}$ and then taking it back to normality.

Substances added in pairs: Afterwards, the substances which were singularly capable of increasing the production of bacteriocins, evaluated by the major peaks (MP), were associated (MP x MP) to evaluate the effect of the combinations on bacteriocin production. 48 different combinations of substances were obtained and added to TSB for E. casseliflavus $416 \mathrm{~K} 1$ (Table 1) and 5 in M17 for L. lactis ATCC 11454 (Table 2).

\begin{tabular}{|c|c|c|c|c|c|}
\hline \multicolumn{2}{|c|}{ Substance combined (g/l) } & \multirow{2}{*}{$\begin{array}{c}\text { Designation associations } \\
=\text { Ass. } 1\end{array}$} & \multicolumn{2}{|c|}{ Substance combined (g/l) } & \multirow{2}{*}{$\begin{array}{c}\text { Designation associations } \\
\text { = Ass. } 25\end{array}$} \\
\hline Vit B1 - (0.1) & Vit B2 - (0.1) & & Vit B2 - (0.1) & Vit B9 - (1) & \\
\hline Vit B1 $-(0.1)$ & Vit B9 - (0.1) & $=$ Ass. 2 & Vit B2 - (0.1) & Vit B3 - (0.1) & $=$ Ass. 26 \\
\hline Vit B1 - (0.1) & Vit B9 - (1) & $=$ Ass. 3 & Vit B2 - (0.1) & Vit B3 - (1) & $=$ Ass. 27 \\
\hline Vit B1 - (0.1) & Vit B3 - (0.1) & $=$ Ass. 4 & Vit B2 - (0.1) & Tw $80-(0.1)$ & $=$ Ass. 28 \\
\hline Vit B1 - (0.1) & Vit B3 - (1) & $=$ Ass. 5 & Vit B2 - (0.1) & $\mathrm{Na} P-(0.1)$ & $=$ Ass. 29 \\
\hline Vit B1 - $(0.1)$ & Tw $80-(0.1)$ & $=$ Ass. 6 & Vit B2 - (0.1) & $\mathrm{Na} P-(1)$ & $=$ Ass. 30 \\
\hline Vit B1 - (0.1) & $\mathrm{Na} P-(0.1)$ & $=$ Ass. 7 & Vit B9 - $(0.1)$ & Vit B3 - (0.1) & $=$ Ass. 31 \\
\hline Vit B1 - (0.1) & $\mathrm{Na} P-(1)$ & $=$ Ass. 8 & Vit B9 - (0.1) & Vit B3 - (1) & $=$ Ass. 32 \\
\hline Vit B1 - (1) & Vit B2 - (0.1) & $=$ Ass. 9 & Vit B9 - $(0.1)$ & Tw $80-(0.1)$ & $=$ Ass. 33 \\
\hline Vit B1 - (1) & Vit B9 - (0.1) & $=$ Ass. 10 & Vit B9 - (0.1) & $\mathrm{Na} P-(0.1)$ & $=$ Ass. 34 \\
\hline Vit B1 - (1) & Vit B3 - (0.1) & $=$ Ass. 11 & Vit B9 - $(0.1)$ & $\mathrm{Na} P-(1)$ & $=$ Ass. 35 \\
\hline Vit B1 - (1) & Vit B3 - (1) & $=$ Ass. 12 & Vit B9 - (1) & Vit B3 - (0.1) & $=$ Ass. 36 \\
\hline Vit B1 - (1) & Tw $80-(0.1)$ & $=$ Ass. 13 & Vit B9 - (1) & Vit B3 - (1) & $=$ Ass. 37 \\
\hline Vit B1 - (1) & $\mathrm{Na} P-(0.1)$ & $=$ Ass. 14 & Vit B9 - (1) & Tw $80-(0.1)$ & $=$ Ass. 38 \\
\hline Vit B1 - (1) & $\mathrm{Na} P-(1)$ & $=$ Ass. 15 & Vit B9 - (1) & $\mathrm{Na} P-(0.1)$ & $=$ Ass. 39 \\
\hline Vit B1 - (10) & Vit B2 - (0.1) & $=$ Ass. 16 & Vit B9 - (1) & $\mathrm{Na} P$ - (1) & $=$ Ass. 40 \\
\hline Vit B1 - (10) & Vit B9 - (0.1) & $=$ Ass. 17 & Vit B3 - (0.1) & Tw $80-(0.1)$ & $=$ Ass. 41 \\
\hline Vit B1 - (10) & Vit B9 - (1) & $=$ Ass. 18 & Vit B3 - (0.1) & $\mathrm{Na} P-(0.1)$ & $=$ Ass. 42 \\
\hline Vit B1 - (10) & Vit B3 - (0.1) & $=$ Ass. 19 & Vit B3 - (0.1) & $\mathrm{Na} P$ - (1) & $=$ Ass. 43 \\
\hline Vit B1 - (10) & Vit B3 - (1) & $=$ Ass. 20 & Vit B3 - (1) & Tw $80-(0.1)$ & $=$ Ass. 44 \\
\hline Vit B1 - (10) & Tw $80-(0.1)$ & $=$ Ass. 21 & Vit B3 - (1) & $\mathrm{Na} P-(0.1)$ & $=$ Ass. 45 \\
\hline Vit B1 - (10) & $\mathrm{Na} P-(0.1)$ & $=$ Ass. 22 & Vit B3 - (1) & $\mathrm{Na} P-(1)$ & $=$ Ass. 46 \\
\hline Vit B1 - (10) & $\mathrm{Na} P$ - (1) & $=$ Ass. 23 & Tw $80-(0.1)$ & $\mathrm{Na} P-(0.1)$ & $=$ Ass. 47 \\
\hline Vit B2 - $(0.1)$ & Vit B9 - (0.1) & $=$ Ass. 24 & Tw $80-(0.1)$ & $\mathrm{Na} P-(1)$ & $=$ Ass. 48 \\
\hline
\end{tabular}

Vit B1, Vit B2, Vit B3, Vit B9: vitamins B1, B2, B3 and B9. Tw 80: Tween 80

Table 1: Associations (MP x MP) for enterocin $416 \mathrm{~K} 1$. 
Citation: Anacarso I, Bondi M, Mura C, de Niederhäusern S, Iseppi R, et al. (2015) Culture Compounds which are Able to Increase the Growth and the Production of Bacteriocins by Two Different LABS. J Plant Pathol Microb 6: 263. doi:10.4172/2157-7471.1000263

Page 3 of 8

\section{Effect of medium composition on bacterial growth}

The effects of the medium composition on bacterial growth were investigated by seeding of the serial dilutions of over-night brothcultures supplemented with singular substances, at three concentrations tested, using TSA for Enterococcus casseliflavus 416 K1 and M17 agar for Lactococcus lactis ATCC 11454, to count the cfu/ml related to the control.

To evaluate the production of bacteriocins and the bacterial growth, a negative control was assessed, represented by the bacterial growth in only the basic medium. All the experiments were performed in triplicate and the results are the mean of all the observations.

\section{Results}

\section{Bacteriocin activity}

The bacteriocin activity from Enterococcus casseliflavus $416 \mathrm{~K} 1$ and Lactococcus lactis ATCC11454 was detected by agar well diffusion assay, using Listeria monocytogenes NCTC 10888 as the indicator strain (Figure 1).

\section{Bacteriocin production under different conditions of growth}

Substances added individually: The halo sizes produced from bacteriocin activity, obtained by addition of the individual 14 different substances at three concentrations to the basic medium, are reported in Figures 2 and 3, referring to the production of bacteriocins by $E$. casseliflavus and L. lactis respectively. For E. casseliflavus $416 \mathrm{~K} 1$ an increase in bacteriocin production was observed in 11 cases in the presence of vitamin B1 $(0.1,1$ and $10, \mathrm{~g} / \mathrm{l})$; vitamin B2 $(0.1 \mathrm{~g} / \mathrm{l})$; vitamin B3 $(0.1$ and $1, \mathrm{~g} / \mathrm{l})$; vitamin $\mathrm{B} 9(0.1$ and $1, \mathrm{~g} / \mathrm{l})$; sodium pyruvate $(0.1$

\begin{tabular}{|c|c|c|}
\hline \multicolumn{2}{|c|}{ Substance combined } & $\begin{array}{c}\text { Designation } \\
\text { associations }\end{array}$ \\
\hline Yeast . - (10) & Na P - (1) & $=$ Ass. 41 a \\
\hline Yeast . - (10) & Na P - (10) & $=$ Ass. 42 a \\
\hline Yeast . - (10) & Amm S - (10) & $=$ Ass. 43 a \\
\hline Na P - (1) & Amm S - (10) & $=$ Ass. 44 a \\
\hline Amm S - (10) & Na P - (10) & $=$ Ass. 45 a \\
\hline
\end{tabular}

Na P: sodium pyruvate; Na S: sodium sulphate; Amm S: ammonium sulphate Table 2: Associations (MP x MP) for nisin A

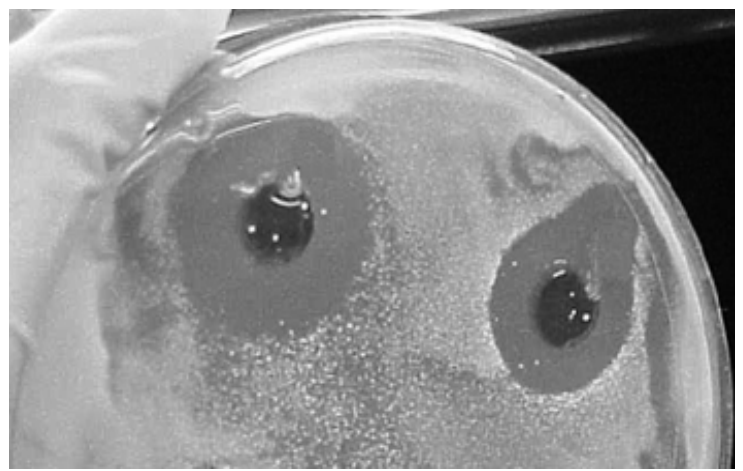

Figure 1: Agar well diffusion assay for detection of bacteriocin activity.

and $1, \mathrm{~g} / \mathrm{l})$ and Tween $80(0.1 \mathrm{~g} / \mathrm{l})$. In particular we showed that all substances tested had an inhibitory effect at the higher concentrations, with the exception of vitamin B1.

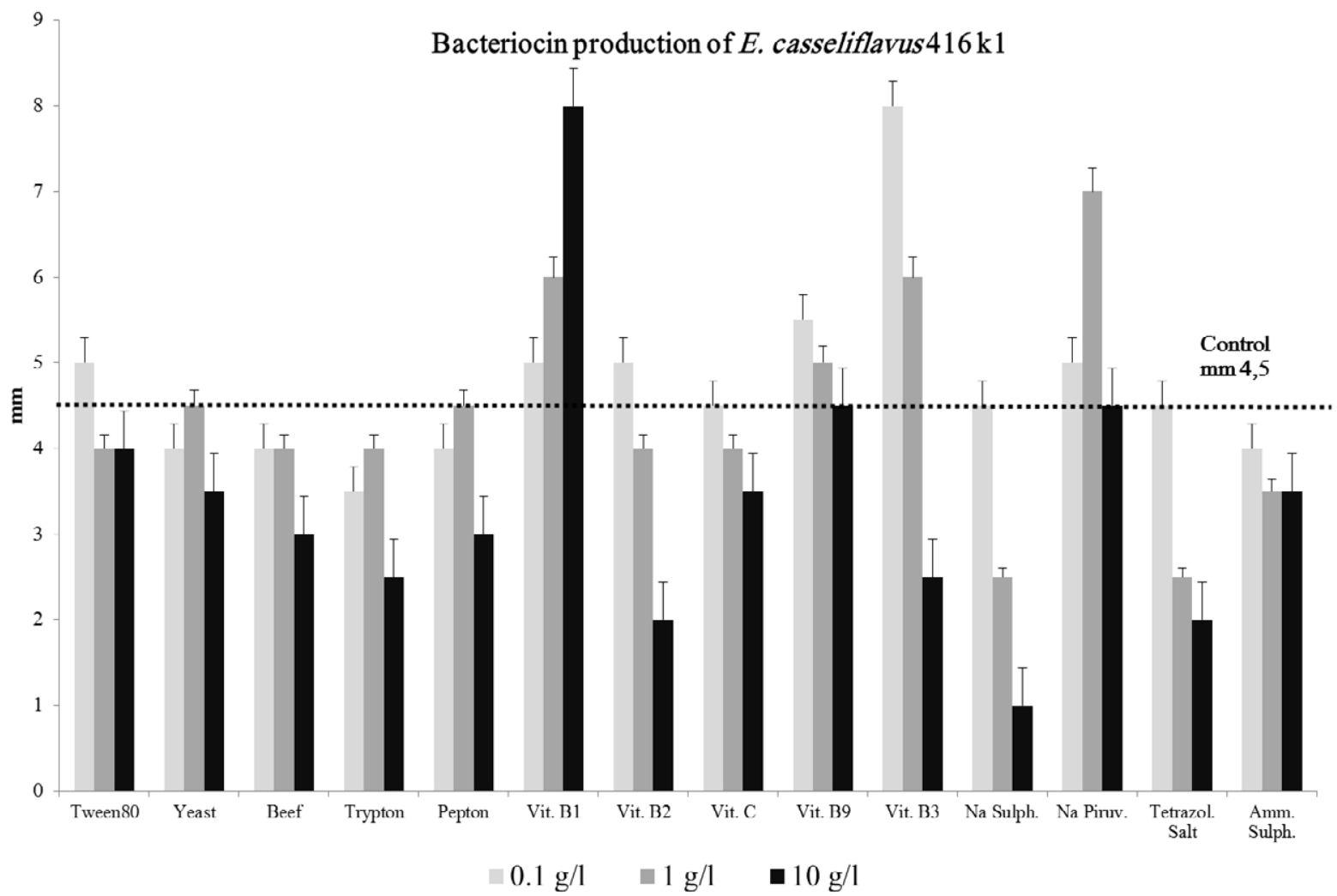

Figure 2: Production of enterocin $416 \mathrm{~K} 1$ under different conditions of growth. 


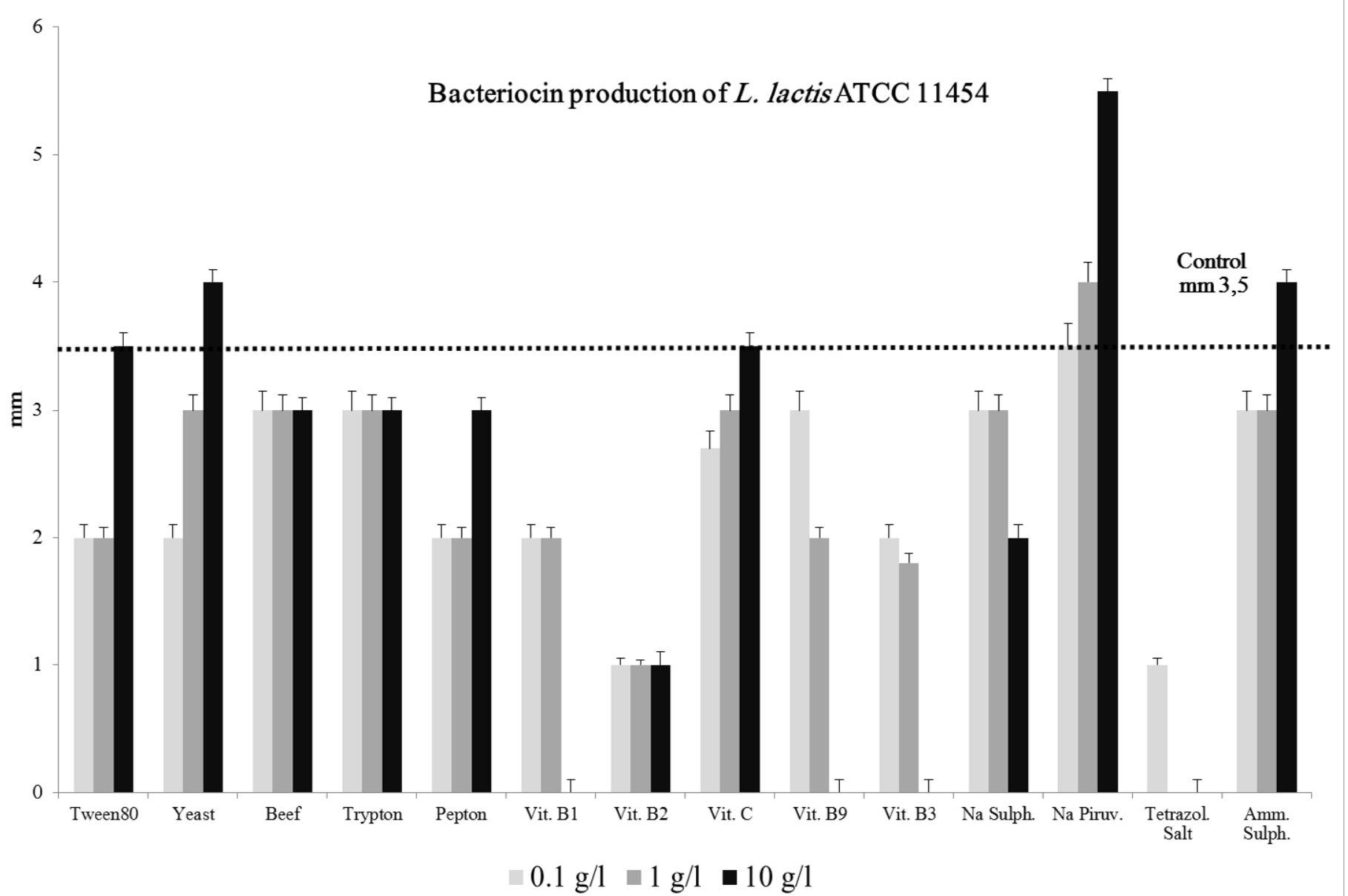

Figure 3: Production of nisin A under different conditions of growth.

For L. lactis all substances added reduced the production of bacteriocin and an increase was observed in only 4 cases (in the presence of high concentrations of yeast extract, $10 \mathrm{~g} / \mathrm{l}$; sodium pyruvate, 1 and 10, g/l; ammonium sulphate, $10 \mathrm{~g} / \mathrm{l}$ ).

Tween 80 at the highest concentration only reached the value of the control, whilst for the others, inhibitory effects were noted. This result in particular is in disagreement with previously published reports on enhanced activity of nisin $\mathrm{A}$ in the presence of Tween 80 [25].

Substances added in pairs: With regard to enterocin $416 \mathrm{~K} 1$, the combination of substances (MP x MP), generated 48 different associations (Ass.1 to Ass.48). In 37 cases (77\%), there was evidence of a marked increase in activity, and then of synergic effects, in particular in 15 cases this rise has shown to be more than twice that of the control value. In 5 cases, instead, in the presence of Ass.1 (vit. B1-0.1 + vit. B2-0.1), Ass.6 (vit. B1-0.1 + Tw 80-0.1\%), Ass.18 (vit B1-10 + vit B9-1), Ass.36 (vit B9-1 + vit B3-0.1), Ass.37 (vit. B9-1+ vit B3-1), there was a decrease in the production of bacteriocin, revealing antagonistic effects (Figures 4 and 5).

With regard to nisin A, the substances that were capable singularly of increasing its production when associated with each other generated only 5 associations (Ass.1a to $5 \mathrm{a}$ ), all with antagonistic effects, with the exception of Ass. 5a (Amm S-10 + Na P-10) in which there was no difference compared to the control (Figure 6). These data show a different behavior of the two LABS used in this study, when the same substances in equal concentrations were added to the basic growth media.

Effect of medium composition on bacterial growth: To determine the possible relationship between total bacterial count and bacteriocin production, cultures of both producers, grown in the different nutritional conditions, were seeded on the solid media previously described and the bacterial count was determined.

With regard to E. casseliflavus $416 \mathrm{~K} 1$ all the substances added at the three concentrations gave positive values of bacterial growth very similar to the control (data not shown). In particular, the protein extracts, at the maximum concentration $(10 \mathrm{~g} / \mathrm{l})$, resulted in an increase of about $1 \mathrm{log}$, except for the meat extract, when an increase was observed at the concentration of $1 \mathrm{~g} / \mathrm{l}$. In contrast, vitamins and salts tested at the higher concentration $(10 \mathrm{~g} / \mathrm{l})$, caused a reduction of microbial growth compared to the control.

With regard to L. lactis ATCC 11454, an increase in the bacterial count was evident only in the presence of the two salts, sodium pyruvate and ammonium sulfate both at $10 \mathrm{~g} / \mathrm{l}$, (data not shown), while all the other substances tested showed a negative effect compared to the control. In particular, vitamin B3 showed a clear inhibitory effect on the growth of L. lactis: reducing the viable count of $5 \log$ if added at 10 $\mathrm{g} / \mathrm{l}$, and of $3 \log$ if added at $1 \mathrm{~g} / \mathrm{l}$.

In this preliminary paper, our aim was to assess how some 
Citation: Anacarso I, Bondi M, Mura C, de Niederhäusern S, Iseppi R, et al. (2015) Culture Compounds which are Able to Increase the Growth and the Production of Bacteriocins by Two Different LABS. J Plant Pathol Microb 6: 263. doi:10.4172/2157-7471.1000263

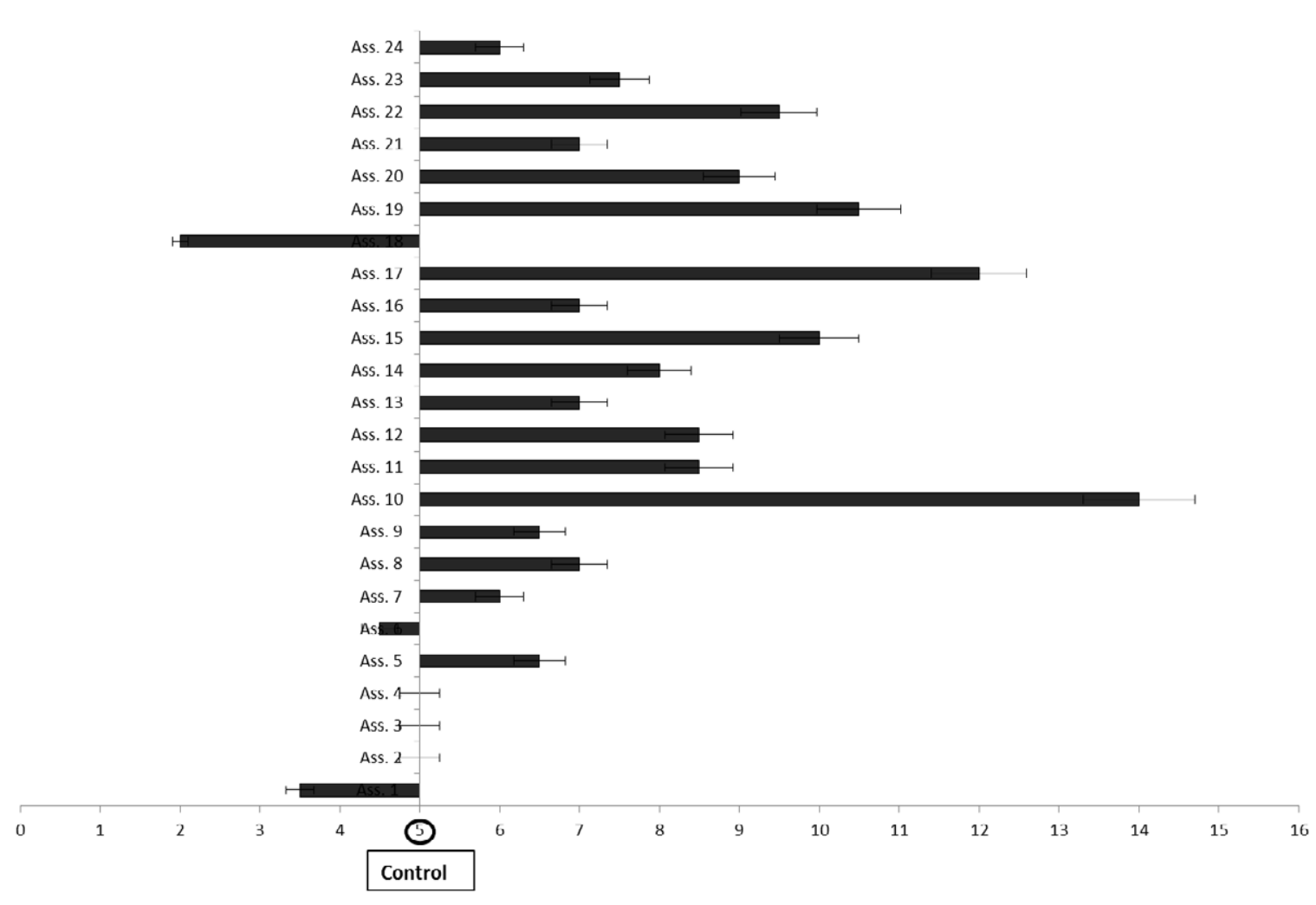

Figure 4: MP x MP and production of enterocin $416 \mathrm{~K} 1$, from Ass. 1 to Ass 24 .

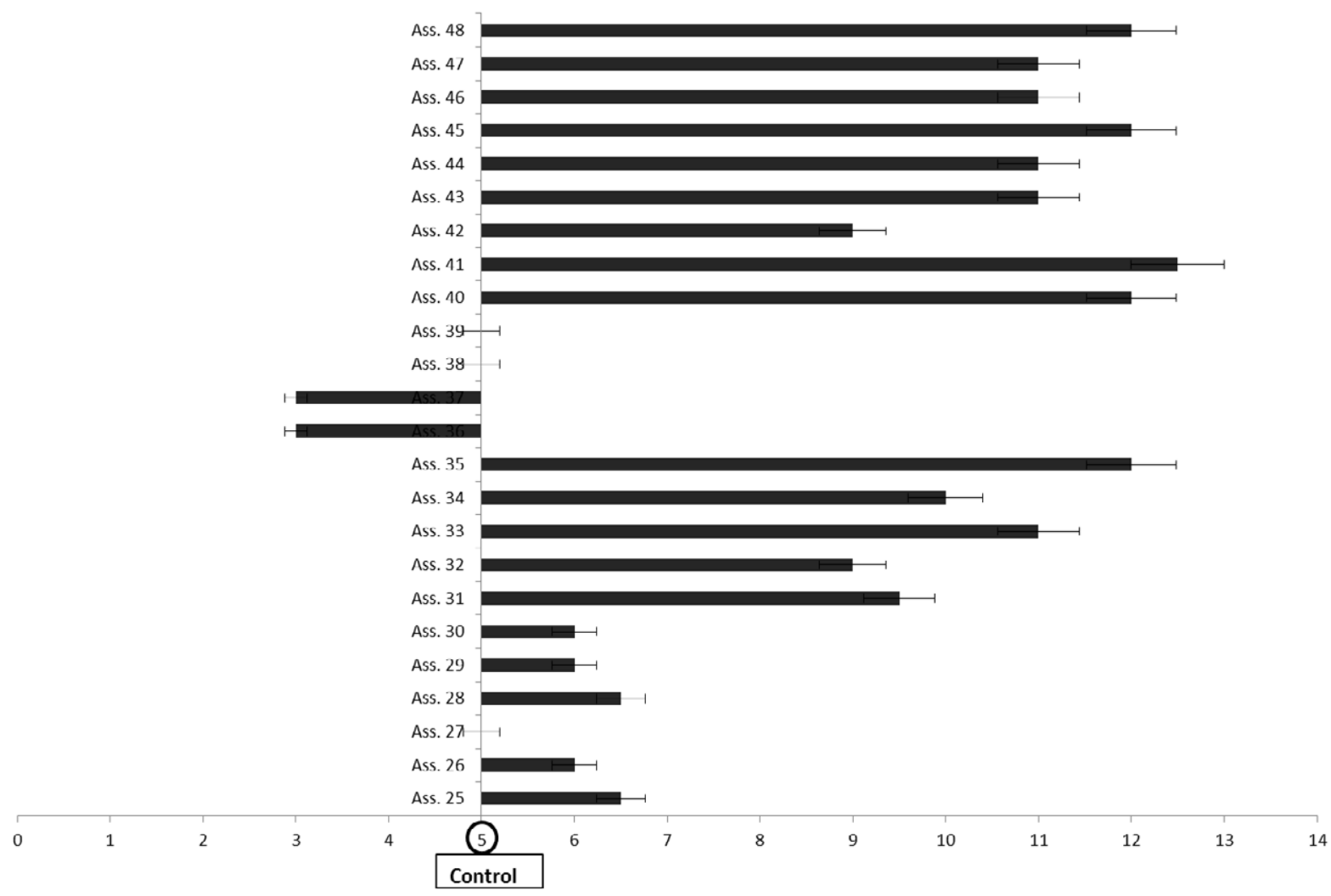

Figure 5: MP x MP and production of enterocin $416 \mathrm{~K} 1$, from Ass. 25 to Ass 48. 
Citation: Anacarso I, Bondi M, Mura C, de Niederhäusern S, Iseppi R, et al. (2015) Culture Compounds which are Able to Increase the Growth and the Production of Bacteriocins by Two Different LABS. J Plant Pathol Microb 6: 263. doi:10.4172/2157-7471.1000263

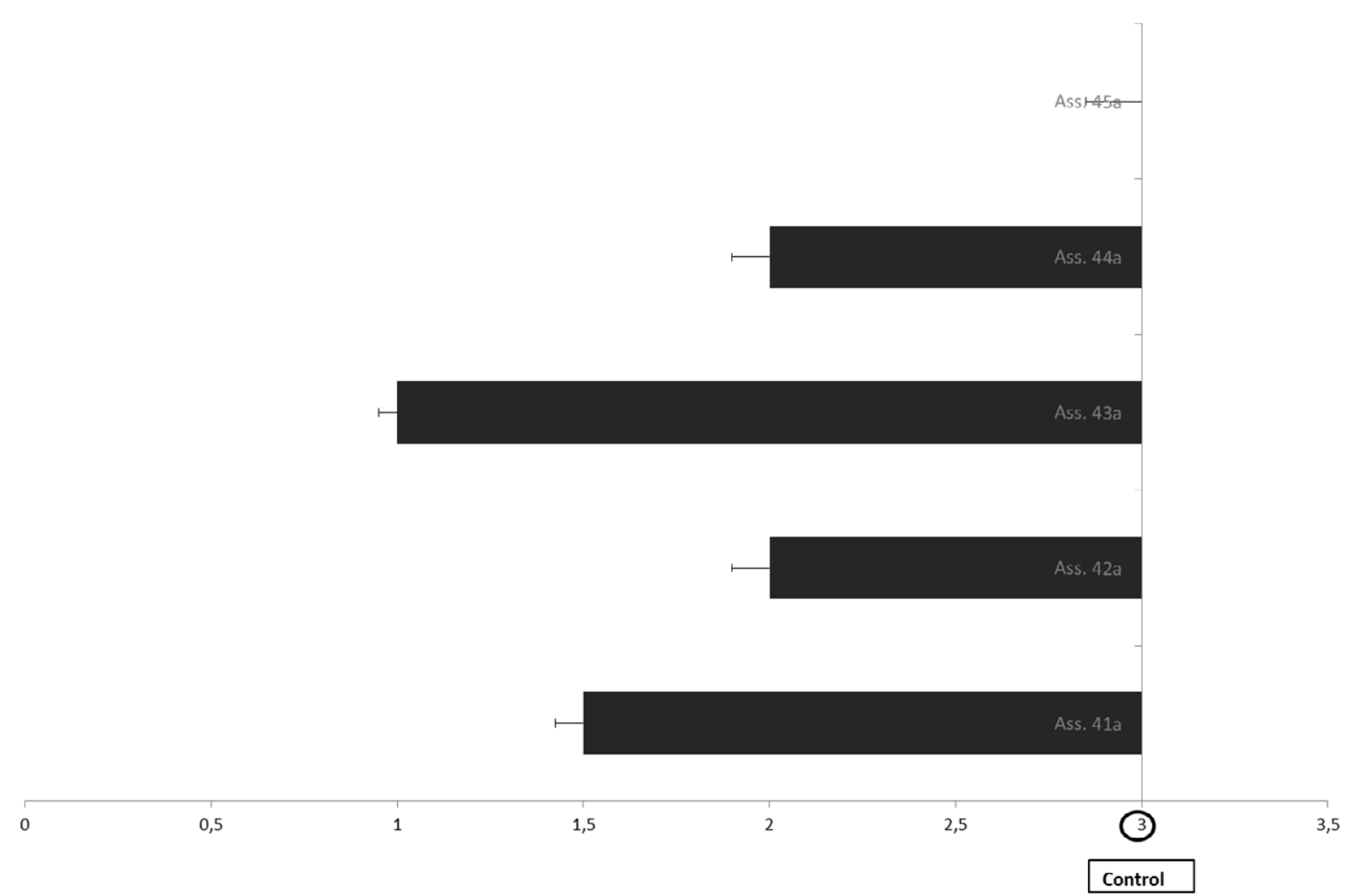

Figure 6: MP $\times$ MP and production of nisin A, from Ass. 1a to Ass. 5a.

substances, including 5 different vitamins, at the concentrations tested, were capable of producing an increase in the bacteriocin activity of $E$. casseliflavus $416 \mathrm{~K} 1$ and L. lactis ATCC11454.

\section{Discussion}

The study was divided into two distinct phases. In the first, the substances were individually added as additional nutrients in order to evaluate the effects on the production of bacteriocins. In the second part, individual substances were combined with each other to highlight the presence of a possible synergism or antagonism.

The first consideration which emerged in this study was the different behavior observed for the two microorganisms tested. With regard to E. casseliflavus $416 \mathrm{~K} 1$, the addition of the individual substances to the basic culture medium produced an increase in growth and bacteriocin activity in many cases. In particular for the tetrazolium salts, sodium sulfate and vitamins B2, B3, B9, C, the higher the concentration added to the medium, the lower the beneficial effects of these substances on growth and bacteriocin production of Enterococcus casseliflavus 416 K1. This behavior was also shown by Ansari et al. [26] with the use of $\mathrm{NaCl}$. An exception was observed for vitamin $\mathrm{B} 1$ which produced an increase in bacteriocins when present at the highest concentration.

L. lactis ATCC 11454 showed different behavior, because its bacteriocin production seemed to be strongly inhibited by the individual substances added; this microorganism is probably negatively conditioned by changes in the culture medium. However there were few exceptions, in fact, some substances were able to promote an increase in the bacteriocin activity of L.lactis, in particular the yeast extract and the ammonium sulfate, both at a concentration of $10 \mathrm{~g} / \mathrm{l}$ and the sodium pyruvate at concentrations of 1 and $10 \mathrm{~g} / \mathrm{l}$.
In the second phase of our study, various combinations of substances were added to the basic medium. These associations were made by combining together the substances that, in the first phase, were capable of increasing the production of bacteriocins when added singularly.

With regard to E. casseliflavus $416 \mathrm{~K} 1$, different results were observed depending on the concentrations of the associated substances.

-Vitamin B1-vitamin B2: if added singularly caused a considerable increase in the production of enterocin $416 \mathrm{~K} 1$. In combination, instead, they produced antagonism when present at high concentrations.

-Vitamin B1-vitamin B9: a synergistic effect occurred when vit. B9 was present in very low quantities $(0.1 \mathrm{~g} / \mathrm{l})$ but only if vitamin $\mathrm{B} 1$ was in surplus (Ass 10 and Ass 17); in other cases, no difference was seen compared to the control or antagonistic effects noted.

-Vitamin B3-vitamin B9: an interesting situation occurred even when these substances were associated. Singularly at the highest concentration tested, Vitamins B3 and B9 inhibited enterocin 416 K1 production, while at low concentrations $(1$ and $0.1 \mathrm{~g} / \mathrm{l})$, they produced an increase in bacteriocin activity. Four associations were created by combining the concentrations which gave the highest peaks (Ass 31, Ass 32, Ass 36 and Ass 37). When vit B9 was present at the lowest concentration, amplification of bacteriocin production was observed (Ass 31, Ass 31) while when the vit B9 was present at $1 \mathrm{~g} / \mathrm{l}$, negative effects were observed. Synergic or antagonistic effects were observed when vit B3 and Vit B9 were associated, and positive or negative effects were attributable of the concentration of these vitamins.

-Sodium pyruvate: this was the only substance that, singularly, increased the bacteriocin activity of both strains studied at the 
Citation: Anacarso I, Bondi M, Mura C, de Niederhäusern S, Iseppi R, et al. (2015) Culture Compounds which are Able to Increase the Growth and the Production of Bacteriocins by Two Different LABS. J Plant Pathol Microb 6: 263. doi:10.4172/2157-7471.1000263

concentrations of 0.1 and $1 \mathrm{~g} / \mathrm{l}$, and 1 and $10 \mathrm{~g} / \mathrm{l}$, for Enterococcus casseliflavus $416 \mathrm{~K} 1$ and Lactococcus lactis ATCC 11454 respectively (Figures 2 and 3).

With regard to L. lactis, all substances that individually increased bacteriocin activity when associated showed strong antagonism except for the Ass.45a (Amm S-10 + Na P-10) which gave results comparable to the control. In particular the sodium pyruvate $(10 \mathrm{~g} / \mathrm{l})$ which, singularly, greatly increased the nisin A activity, if associated with yeast extract $(10 \mathrm{~g} / \mathrm{l})$ produced antagonistic effects while if associated with ammonium sulphate $(10 \mathrm{~g} / \mathrm{l})$, results which were only equal to the control were observed (Ass 45a)

Other authors have reported the influence of different substances on the production of bacteriocins, especially with regard to protein substances or different salts, but little is reported on the use of different vitamins $[16,27,28]$. In this study it was demonstrated that the concentration of some substances influences the production of bacteriocin. Vitamins used singularly in this study showed a positive influence only for enterocin $416 \mathrm{~K} 1$ if present at low concentrations, except vit. B1 (10 g/l) which increased production.

Regarding nisin A, all vitamins tested showed a negative effect on production. The only substance that gave beneficial effects for both bacteria was sodium pyruvate.

The production of bacterial substances, such as bacteriocins, which are attracting ever more interest for their potential use as natural preservatives in food or in clinical fields, can thus be increased by using additional nutrients. To obtain encouraging results, it becomes crucial to understand the effects that the nutrients can have on bacterial metabolism, in order to be able to use the individual nutrients or mixtures of these, using known quantities and in the correct combinations. This is a preliminary study and thus not exhaustive and leaves many questions open, even if in the few studies reported in the literature related to this topic, all the mechanisms that lead to the production and release of bacteriocins by bacteria have not yet been clarified.

Finally, with regard to the influence on bacterial growth (data not shown), it was observed that the addition of most of the substances caused, also in this case, two different behaviors in the two producer strains. With regard to Enterococcus casseliflavus $416 \mathrm{~K} 1$, the addition of different substances produced positive effects, except for the vitamins and salts tested, which caused a reduction in microbial growth if presents at higher concentrations $(10 \mathrm{~g} / \mathrm{l})$. Lower concentrations, except for vit B1, caused increases in Enterococcus casseliflavus $416 \mathrm{~K} 1$ growth, and consecutively an increase in production of bacteriocins was observed.

With regard to L. lactis ATCC11454, in general all substances added produced negative effects on growth, only ammonium sulphate and sodium pyruvate, added to the basic medium at the highest concentrations, slightly increased $L$. lactis growth.

The importance of the nutrients and of their concentration were the optimum production of bacteriocin from Bacillus subtilis KIBGE IB-17 there was at low concentration of $\mathrm{NaCl}$, trypton and yeast extract. Other authors have studied this aspect [26], Qiuju et al. [16] reported that increasing the concentration of Tween 20 decrease the bacteriocin activity of different LABs isolated from gut of poultry. Verluyten et al. [29] studied the effect of the depletion of the individual components of the MRS had on the production of curvacin by Lactobacillus curvatus LTH 1174. In this work, differently, we have studied the effects that some substances added as supplement nutrient may have on the growth and bacteriocin production of two LAB. In conclusion different considerations are possible: Enterococcus casseliflavus 416 and Lactococcus lactis ATCC K1 have a different behavior by adding the same substances at a basic medium, with beneficial effects for the first strain, if the concentration is low, and negative for the second that not tolerates changes in its growth medium. The other important consideration that emerges from this study is that the concentration of supplement substances strongly influences the production of bacteriocins and these data highlight the importance to fine tune the nutrients and micronutrients for a greater production of bacteriocin.

\section{References}

1. Badel S, Bernardi T, Michaud P (2011) New perspectives for Lactobacilli exopolysaccharides. Biotechnol Adv 29: 54-66.

2. Cladera-Olivera F, Caron GR, Brandelli A (2004) Bacteriocin-like substance production by Bacillus licheniformis strain P40. Lett Appl Microbiol 38: 251-256.

3. Klaenhammer TR (1988) Bacteriocins of lactic acid bacteria. Biochimie 70 337-349.

4. Nes IF, Holo H (2000) Class II antimicrobial peptides from lactic acid bacteria Biopolymers 55: 50-61.

5. Chahad OB, EI Bour M, Calo-Mata $P$, Boudabous A, Barros-Velàzquez J (2012) Discovery of novel biopreservation agents with inhibitory effects on growth of food-borne pathogens and their application to seafood products. Res Microbiol 163: 44-54

6. Settanni L, Corsetti A (2008) Application of bacteriocins in vegetable food biopreservation. Int J Food Microbiol 121: 123-138.

7. Lohans CT, Vederas JC (2012) Development of Class Ila Bacteriocins as Therapeutic Agents. Int J Microbiol 2012: 386410.

8. Diez-Gonzalez F (2007) Applications of bacteriocins in livestock. Curr Issues Intest Microbiol 8: 15-23.

9. Sabia C de Niederhäusern S, Messi P, Manicardi G, Bondi M (2003) Bacteriocinproducing Enterococcus casseliflavus IM 416K1, a natural antagonist for control of Listeria monocytogenes in Italian sausages ("cacciatore"). Int J Food Microbiol 87: 173-179.

10. Vidhyasagar V, Jeevaratnam K (2013) Bacteriocin activity against various pathogens produced by Pediococcus pentosaceus VJ13 isolated from Idly batter. Biomed Chromatogr 27: 1497-1502.

11. Hammami R, Fernandez B, Lacroix C, Fliss I (2013) Anti-infective properties of bacteriocins: an update. Cell Mol Life Sci 70: 2947-2967.

12. Nawaz SK, Riaz S, Hasnain S (2009) Screening for anti-methicillin resistant Staphylococcus aureus (MRSA) bacteriocin producing bacteria. African Journal of Biotechnology 8:365-368.

13. Diop MB, Dubois-Dauphin R, Tine E, Ngom A, Destain J, Thonart P (2007) Bacteriocin producers from traditional food products. Biotechnology Agronomy Society and Environmental 11:275-281.

14. Hammami I, Rhouma A, Jaouadi B, Rebai A, Nesme X (2009) Optimization and biochemical characterization of a bacteriocin from a newly isolated Bacillus subtilis strain 14B for biocontrol of Agrobacterium spp. strains. Lett Appl Microbiol 48: 253-260.

15. Nilsen T, Nes IF, Holo H (1998) An exported inducer peptide regulates bacteriocin production in Enterococcus faecium CTC492. J Bacteriol 180: 1848-1854.

16. Qiuju W, Yizhe C, Dale L, Ling Y, Jili X, et al. (2010) Effect of cultural components on antimicrobial activity of bacteriocin produced by bacteria isolated from gut of poultry. African J Microbiol Research 4:1970-1980.

17. Todorov SD, Dicks LM (2006) Effect of medium components on bacteriocin production by Lactobacillus plantarum strains ST23LD and ST341LD, isolated from spoiled olive brine. Microbiol Res 161: 102-108.

18. Sabia C, Manicardi G, Messi P, de Niederhäusern S, Bondi M (2002) Enterocin $416 \mathrm{~K} 1$, an antilisterial bacteriocin produced by Enterococcus casseliflavus IM 416K1 isolated from Italian sausages. Int J Food Microbiol 75: 163-170.

19. Yi H, Han X, Yang Y, Liu W, Liu H, et al. (2013) Effect of exogenous factors on 
Citation: Anacarso I, Bondi M, Mura C, de Niederhäusern S, Iseppi R, et al. (2015) Culture Compounds which are Able to Increase the Growth and the Production of Bacteriocins by Two Different LABS. J Plant Pathol Microb 6: 263. doi:10.4172/2157-7471.1000263

Page 8 of 8

bacteriocin production from Lactobacillus paracasei $\mathrm{J} 23$ by using a resting cell system. Int J Mol Sci 14: 24355-24365.

20. Miret JA, Munné-Bosch S (2014) Plant amino acid-derived vitamins: biosynthesis and function. Amino Acids 46: 809-824.

21. Neal RA (1970) Bacterial metabolism of thiamine. 3. Metabolism of thiamine to 3-(2'-methyl-4'-amino-5'-pyrimidylmethyl)-4-methyl-thiazole-5-acetic acid (thiamine acetic acid) by a flavoprotein isolated from a soil microorganism. J Biol Chem 245: 2599-2604

22. Edwards RL, Bryan A, Jules M, Harada K, Buchrieser C, et al. (2013) Nicotinic acid modulates Legionella pneumophila gene expression and induces virulence traits. Infect Immun 81: 945-955.

23. Hemberger S, Pedrolli DB, Stolz J, Vogl C, Lehmann M, et al. (2011) RibM from Streptomyces davawensis is a riboflavin/roseoflavin transporter and may be useful for the optimization of riboflavin production strains. BMC Biotechnol 11: 119 .

24. Nwunuji TP, Mayowa OO, Yusoff SM, Bejo SK, Salisi S, et al. (2014) The ameliorative effect of ascorbic acid on the oxidative status, live weight and recovery rate in road transport stressed goats in a hot humid tropical environment. Anim Sci J 85: 611-616.

25. Penna TC, Moraes DA (2002) Optimization of nisin production by Lactococcus lactis. Appl Biochem Biotechnol 98-100: 775-89.

26. Ansari A, Aman A, Siddiqui NN, lqbal S, Ali ul Qader S (2012) Bacteriocin (BAC-IB17): screening, isolation and production from Bacillus subtilis KIBGE IB-17. Pak J Pharm Sci 25: 195-201.

27. Aasen IM, Møretrø T, Katla T, Axelsson L, Storrø I (2000) Influence of complex nutrients, temperature and $\mathrm{pH}$ on bacteriocin production by Lactobacillus sake CCUG 42687. Appl Microbiol Biotechnol 53: 159-166.

28. Gromova OA, Torshin Ilu, Garas'ko EV, Limanova OA, Grishina TR, et al. (2013) [System analysis of the relationship between the metabolism of vitamins by micro-biota and the survival of the positive microflora of the digestive tract] Eksp Klin Gastroenterol : 28-36.

29. Verluyten J, Leroy F, De Vuyst L (2004) Influence of complex nutrient source on growth of and curvacin a production by sausage isolate Lactobacillus curvatus LTH 1174. Appl Environ Microbiol 70: 5081-5088. 